DOI: https://doi.org/10.24144/2409-6857.2018.2(52).53-56

УДК 339.543

Кампо Г. М., Биркович Л. М.

\title{
КОНТРОЛЬНА ДІЯЛЬНІСТЬ МИТНИХ ОРГАНІВ У ПРОЦЕСІ ЗАБЕЗПЕЧЕННЯ ЕКОНОМІЧНОЇ БЕЗПЕКИ ДЕРЖАВИ
}

\begin{abstract}
У статті визначено роль контрольної діяльності митних органів у прочесі забезпечення економічної безпеки держави та ї̈ вплив на економіку в цілому. Зроблено порівняння обсягу імпорту та експорту з попереднім роком. Досліджено вплив контрабанди та економіку Украӥни. Узагальнено підходи щуодо підвищення ефективності митного контролю для забезпечення національної безпеки держави.
\end{abstract}

Ключові слова: економічна безпека, зовнішньоекономічна діяльність, митний контроль, митне оподаткування, чистий експорт, імпорт, контрабандні товари, порушення митних правил.

Постановка проблеми. В сучасних умовах глобалізації проблема забезпечення економічної безпеки України стає все більш гострою. Зовнішня агресія з боку Російської Федерації, перманентне зростання викликів та загроз безпеці на глобальному рівні, значне збільшення зовнішньоекономічних зв'язків вимагає посиленого контролю 3 боку митних органів. Головним інструментом у процесі забезпечення економічної безпеки через діяльність митних органів виступає митний контроль. Митні органи, за своїм призначенням покликані захищати країну від зовнішніх загроз і забезпечують економічну безпеку країни через виконання своїх функцій фіскальної та регулятивної.

Недооцінювання важливості економічної безпеки як на національному, так і міжнародному рівні може призвести до небажаних катастрофічних наслідків, наприклад, занепаду галузей економіки, зменшення рівня життя населення, що призводить до підриву системи життєдіяльності нації 3 можливою подальшою втратою суверенітету.

Аналіз останніх досліджень і публікацій. Як свідчить аналіз досліджень, вивченням питання економічної безпеки займаються як вітчизняні, так і зарубіжні вчені, серед яких можна відмітити: I. Бережнюка, М. Губа, П. Пашка, О. Івашину, А Мазура, Я. Жаліло, П. Саблука, С. Ківалова, А. Калініченка та інших провідних науковців.

(c) Кампо Георгіна Михайлівна, к.е.н., доцент кафедри фінансів та банківської справи ДВНЗ «Ужгородський національний університет», м.Ужгород, Україна, e-mail: heorgina.kampo@uzhnu.edu.ua, тел:+380509210907

Биркович Ліана Михайлівна, магістр ДВНЗ «Ужгородський національний унверситет», агент з митного оформлення у ТОВ «Твоя логістика», м.Ужгород, Україна, e-mail: lianabyrkovych1995@gmail.com., тел.+:380953368948
Разом 3 цим, деякі аспекти даної проблеми потребують додаткового вивчення, зокрема щодо визначення сутності та критеріїв економічної безпеки держави $з$ погляду впливу на неї митних органів ДФС України.

Основне завдання статті полягає у дослідженні впливу контрольної діяльності митних органів на забезпечення економічної безпеки держави.

Виклад основного матеріалу. В умовах глобалізації розвиток економіки та рівень життя населення залежить не лише від внутрішньої економічної політики, а й від ефективної зовнішньоекономічної діяльності, від захисту внутрішнього ринку. Передусім йдеться про контроль митних органів за експорно-імпортними операціями, який спрямовується на захист національного товаровиробника, боротьбу 3 тіньовою економікою та захист національних економічних інтересів у сфері зовнішньоекономічної діяльності.

Зовнішньоекономічна безпека прямо пов'язана 3 митним оподаткуванням. Через диференціацію ставок митного тарифу система митного оподаткування, 3 одного боку, слугує запобіжником контрабанди товарів, нераціональної структури імпорту й експорту, від'ємного сальдо зовнішньої торгівлі, а з іншого - сприяє вільному руху товарів, робочої сили та капіталу, що створює сприятливі умови для розвитку національної економіки завдяки іiі інтеграції у світовий розподіл праці. Можна стверджувати, що митна безпека безпосередньо або опосередковано впливає майже на кожен складник економічної безпеки держави $[1, \mathrm{c}$. 23-26].

Так, за інформацією Державної служби статистики (Держстату) України, обсяг експорту товарів і послуг України у 2017 р. становив 52 329,6 млн дол. США, а імпорту товарів та послуг 
- 54 955,0 млн дол. Порівняно з 2016 р. зростання експорту відбулося на $16 \%$, а імпорту - на 23,3\%. Негативне сальдо зовнішньоторговельного балансу у 2017 р. становило 2625,4 млн дол. (при чому у 2016 p. сальдо було позитивним i становило 541,6 млн дол.). В 2017 р. обсяг експорту товарів з України становив 43 266,6 млн дол. США, а обсяг імпорту - 49 598,5 млн дол. Порівняно з 2016 р. експорт мав тенденсію до зростання на $19 \%$ (на 6904,9 млн дол.), а імпорт на 26,4 \% (на $10 \quad 348,7$ млн дол.). Завдяки випереджаючому зростанню імпорту товарів, порівняно 3 експортом негативне сальдо української зовнішньої торгівлі товарами у 2017 р. становило 6331,9 млн дол. У 2016 р. сальдо української зовнішньої торгівлі товарами було також негативним, але за абсолютним значенням менше, ніж у 2017 р. - 2888,1 млн дол. Коефіцієнт покриття експортом імпорту товарів в Україну становив 0,87 , а в 2016 р. - 0,93 [7].

На сьогоднішній час актуальним $є$ питання контрабанди товарів в Україну. Надходження від митних платежів до державного бюджету становлять одну третину від загального їх обсягу. Проте внаслідок такого явища, як контрабанда скорочується надходження коштів, тим самим створюються небезпеки та загрози фінансовій та економічній безпеці держави. Явище контрабанди та сірого імпорту, яке сьогодні має місце на кордоні України, є одним з найбільших репутаційних ризиків і викликів для України. За неофіційними даними рівень тіньових оборудок сягає $60-80 \%$, а в абсолютних цифрах - 70-100 млрд грн. Це гроші, які проходять повз державний бюджет. I це ті втрати, які несе Україна, як держава. В Україні втрати бюджету внаслідок контрабанди на рік складають 4 млрд доларів.

Причинами зростання контрабанди $є$ :

-невиправдано високі ставки окремих видів податків і зборів;

-низький рівень податкового i митного контролю;

-корумпованість

контролюючих органів;

-невідповідність рівня податкових та митних ставок, а також економічної ситуації, низький рівень добробуту громадян, коли малозабезпечені люди, під впливом безвихіддя, свідомо беруть участь у нелегальному бізнесі.

Відомо, що основними предметами контрабанди є промислові та продовольчі товари, транспортні засоби, наркотичні засоби, зброя, боєприпаси, історичні та культурні цінності, валюта, аудіо-, відео-, комп'ютерна та побутова техніка, тютюн, нафтопродукти, ювелірні вироби.

Тютюнові вироби - це нині найпоширеніший вид контрабанди. Цигарки перевозять або у вантажах, де важко зробити перевірку (торф у мішках), або у спеціальних сховищах, доступ до яких можна отримати після відвантаження товару. Другим після тютюну $\epsilon$ незаконне ввезення м'яса та м'ясопродуктів [2, с. 113-118].

Значного поширення набули факти контрабанди та порушення митних правил під час увезення автотранспортних засобів. Їх реальна вартість занижується від трьох до двадцяти разів. Автомобілі оформлюються як нові, хоча вже мають строк експлуатації рік або півроку. Довести, що такий автомобіль не новий, украй важко. В Україну також увозять автомобілі 3 великим строком експлуатації (понад 8 років) та оформлюють як гуманітарну допомогу. $€$ факти вивезення вантажу із зазначенням у документації свідомо неправильних відомостей щодо їх вартості. Також дуже часто зазначаються неіснуючі підприємства-покупці або продавці виробники товару. Такі угоди переважно фіктивні. Поширений також імпорт товарів від фірм, що зареєстровані в офшорних зонах, які можуть здійснювати збиткові поставки товарів в Україну із заниженням вартості через митні ліцензійні склади [11, с. 59-61].

За даними Державної фіскальної служби України митницями ДФС протягом I півріччя 2018 року виявлено понад 22,4 тис порушень митних правил. Кількість складених протоколів про порушення митних правил у порівнянні 3 аналогічним періодом минулого року збільшилась на 58 відсотків або на 8,2 тис. справ. У понад 2,6 тис. справах про порушення митних правил тимчасово вилучено предмети правопорушень на суму 389 млн грн [8].

Середня вартість реально вилучених предметів правопорушення у 1 справі склала 149 тис. грн та збільшилась на $12 \%$ порівняно 3 минулим роком. Безпосередньо митницями ДФС розглянуто понад 17 тис. справ про порушення митних правил. Це у 2,1 рази більше, ніж за 6 місяців 2017 року. Застосовано адміністративне стягнення у вигляді штрафу на суму 9,27 млрд грн, $з$ яких стягнуто до Держбюджету на суму 53 млн грн. Це у 2,7 рази перевищує показник аналогічного періоду минулого року. На розгляд до суду митницями передано понад 2,8 тис. справ про порушення митних правил на суму 702 млн грн. За результатами розгляду справ про порушення митних правил судом прийнято рішення про накладення стягнень у вигляді штрафу та конфіскації на суму 210 млн грн. Сума конфіскованих товарів склала 117 млн грн. Також за січень - червень 2016 року судом накладено стягнень у вигляді штрафу на суму 92 млн. грн. У той же час, судами закрито провадження у 377 
справах про порушення митних правил на суму 231 млн грн, що на $21 \%$ менше по кількості, та на $25 \%$ - по вартості предметів правопорушень порівняно з відповідним періодом минулого року [8].

Отже, контрабандні потоки товарів - це дуже поширений спосіб ввезення товарів на територію України. Така діяльність впливає на всі сфери економічного життя країни. Сучасна контрабанда - одна зі складових організованої злочинності у сфері економіки. Тому боротьба 3 контрабандою - першочергове завдання не тільки митної служби, але й держави взагалі, адже потерпає від цього явища насамперед державний бюджет.

У чинному законодавстві України не існує чітко й повно визначених ознак такого виду діяльності, як боротьба 3 контрабандою та іï організація,

безпосередньо не висвітлено іiі основні форми, сили, методи і засоби, спрямовані на досягнення поставленої мети. Тому для формулювання поняття організації боротьби 3 контрабандою та їі змісту потрібно звернутись до приписів, передбачених у законах та нормативних актах, що регулюють правоохоронну діяльність взагалі [5, c. 79].

Боротьба $з$ контрабандою - це вид державної діяльності, підрозділами яку державних правоохоронних виконують органів, що наділені повноваженнями щодо боротьби зі злочинністю законами України та іншими нормативно-правовими актами.

Для забезпечення запобіганню контрабанди необхідно вжити таких заходів:

- розробка, впровадження у практику технічних засобів митного контролю та митного оформлення, упровадження новітніх технологій;

- удосконалення діяльності всіх суб'єктів профілактики порушень митних правил;

- підвищення професійної та правової підготовки працівників митниць, покращення їх соціального та фінансового забезпечення тощо;

- належне правове забезпечення профілактичної діяльності суб'єктів та інше [10, c. 35$]$.

Методи боротьби можуть бути умовно розділені на кілька розділів:

- профілактика правопорушень: постійний моніторинг ринку, проведення попе- реджувальних заходів, інформаційнороз'яснювальна кампанія в 3МI;

- фіксація правопорушень: проведення перевірок контролюючими органами, проведення контрольних закупівель, експертиз, вилучення «сумнівної» продукції тощо, 3 подальшим притягненням порушників до відповідальності;

- співпраця 3 уповноваженими державними органами з метою відстеження та закриття схем та маршрутів несанкціонованого (контрабандного) ввезення товарів в Україну;

- судове переслідування порушників 3 метою припинення порушень та отримання компенсації чи відшкодування збитків для правовласника [4, c. 120].

На нашу думку, першочергове завдання держави - це боротьба саме 3 контрабандою. Це дозволить країні отримати додаткові кошти для наповнення бюджету, захистити національного товаровиробника, зменшити рівень корупції тощо. Для реалізації цих цілей необхідним $\epsilon$ запровадження системи конкретних контролінгових заходів та методів стратегічного і тактичного характеру, які здійснюються уповноваженими державними органами задля реалізації мети i завдань боротьби 3 контрабандою.

Удосконалення митного контролю $\epsilon$ надзвичайно важливим для захисту національних інтересів. При цьому митна справа виступає не лише як інструмент i провідник зовнішньоекономічної діяльності, а й має важливе значення, стаючи регулятором i засобом формування нових економічних відносин та зв'язків [6, с. 128-150].

Висновки i перспективи подальших досліджень. Таким чином, можна зробити висновок, що удосконалення митного контролю $є$ важливою складовою посилення економічної безпеки держави. 3 метою підвищення ефективності митного контролю необхідним є посилення боротьби з контрабандою, запобігання порушення митних правил i податкового законодавства, удосконалення контролю за повнотою стягнення митних платежів. Крім того, необхідно забезпечити прозорість митних процедур та ширше застосування сучасних технологій, що дозволять здійснювати митний контроль швидше та якісніше, мінімізувавши людський фактор.

\section{ПЕРЕЛІК ВИКОРИСТАНИХ ДЖЕРЕЛ}

1. Губа М. О. Місце і роль митного оподаткування в системі економічної безпеки держави / М. О. Губа // Економіка, фінанси, право. - 2012. - № 11. - С. 23-26. 
2. Ляшенко О. М. Економічна безпека та національна конкурентоспроможність в умовах глобалізації / О. М. Ляшенко, Б. В. Плескач, В. К. Бантуш // Экономические науки. - 2009. - № 3. - С. 113-118.

3. Макроекономіка :підручник / за ред. В.Д. Базидевича. - 4-е вид., перероб. і доп. - К. : Знання, 2008. - 743c.

4. Митна справа : посібник-практикум / О. С. Кузьмін. - О. Г. Мельник, О. Ю. Григор'єв. - [та ін.] ; за заг. ред. проф. О. С. Кузьміна. - К. : Каравела, 2014. - 232 с.

5. Осадча О.А. // Управління економікою: теорія та практика. - 2012. - № 2012. - С. 128-150.

6. Офіційний сайт Державної служби статистики України [Електронний ресурс]. - Режим доступу : www.ukrstat.gov.ua.

7. Офіційний сайт Державної фіскальної служби України. - [Електронний ресрс]. -Режим доступу: http://www.sfs.gov.ua/

8. Пашко П. В. Митна безпека (теорія, методологія та практичні рекомендації): моногр. / П. В. Пашко. Одеса : ПЛАСКЕ, 2009. - 628 с.

9. Романюк Б. В. Контрабанда: засоби попередження та протидії : навчальний посібник / Б. В. Романюк, М. І Камлик, В. В. Коваленко та ін. ; за ред. Я. Ю. Кондратьєва, Б. В. Романюка. - К. : МІВВЦ, 2011. - 118 с.

10. Срібний В. І. Економічна безпека як складова національної безпеки / В. І. Срібний // Економические науки. - 2009. - № 4. - C. 59-61.

\section{REFERENCES}

1. Guba, M.O. (2012). Mistse i rol mitnogo opodatkuvannya v sistemi ekonomichnoyi bezpeki derzhavi [Place and role of customs taxation in the system of economic security of the state]. Ekonomika, finansy, pravo - Economics, finance, law, 11, 23-26. [in Ukrainian].

2. Lyashenko, O. M., \& Pleskach, B. V., \& Pleskach, B. V. (2009). Ekonomichna bezpeka ta natsionalna konkurentospromozhnist v umovah globalizatsiyi [Economic Security and national competitiveness in the conditions of globalization]. Ekonomicheskie nauki - Economic sciences, 3, 113-118 [in Ukrainian].

3. Basidewicz, V. D. (2008). Makroekonomika [Macroeconomics]. Kyiv: Knowledge [in Ukrainian].

4. Kuzmin, O. E., \& Melnyk, O. G., \& Grigoriev, O. Y. (2014). Mitna sprava: posibnik-praktikum [Customs case: practical guide]. Kyiv: Caravela [in Ukrainian].

5. Osadcha, O. A. (2012) Upravlinnya ekonomikoyu: teoriya ta praktika [Management of economics: theory and practice], 128-150. [in Ukrainian].

6. Ofitsiyniy sayt Derzhavnoyi sluzhbi statystiki Ukrainy [Official site of the State Statistics Service of Ukraine]. Retrieved from: www.ukrstat.gov.ua [in Ukrainian].

7. Ofitsiyniy sayt Derzhavnoyi fiskalnoyi sluzhbi Ukrainy [Official site of the State Fiscal Service of Ukraine]. Retrieved from: http://www.sfs.gov.ua [in Ukrainian].

8. Pashko, P.V. (2009) Mitna bezpeka (teoriya, metodologiya ta praktichni rekomendatsiyi [Customs safety (theory, methodology and practical recommendations)]. Odessa: PLASKE [in Ukrainian].

9. Romanyuk, B.V., \& Kamlik, M. I., \& Kovalenko, V.V., \& Kondratiev, Y., \& Romanyuk, B. V. (2011). Kontrabanda: zasobi poperedzhennya ta protidiyi: navchalniy [Contraband: means of prevention and counteraction]. Kyiv: MIBBTS, [in Ukrainian].

10. Sribny, V.I. (2009). Ekonomichna bezpeka yak skladova natsionalnoyi bezpeky [Economic security as a component of national security], 4, 59-61 [in Ukrainian].

Одержано 14.09.2018 p. 